\title{
NEW NEOLITHIC SETTLEMENT IN MARIUPOL AND ITS PLACE IN THE SYSTEM OF SYNCHRONOUS MONUMENTS
}

\author{
Vladimir N. Gorbov \\ Donetsk Republican (Regional) Museum, Donetsk, Ukraine
}

Aleksandr V. Kolesnik

Donetsk State University, Donetsk, Ukraine

\begin{abstract}
The settlement of Kalmius in the Northeastern Azov Sea region is situated on the left bank of the the Kalmius river in the historical center of the town of Mariupol. This is a mailtilayered site with cultural layers ranging from the Neolithic to Modern Age. The Neolithic layer underwent considerable postdepositional deformations. Cultural remains of the Neolithic period are associated with a buried soil occurring at a considerable depth. The layer has yielded numerous flint artifacts, animal bone fragments, and pottery fragments most of which are represented by small shards. The paper describes the ceramic assemblage, demonstrates the connection between the Kalmius settlement and Mariupol cemetery, and compares the materials of Kalmius with those from the coeval assemblages from the Northern Azov and Lower Don regions. In addition, a special attention is paid to the comparative analysis of flint inventories of the Kalmius settlement and Mariupol cemetery. The flint industry of both sites is based on small and middle-sized blades obtained by pressure-flaking. Similar or identical are also microlithic tools, bifacial points, etc. The period of existence of the Mariupol cemetery seems to have been longer than that of the Neolithic settlement at Kalmius. The difference in clay paste makes it possible to reconstruct two technologies of pottery making. The majority of ceramic fragments are decorated with tooth-stamp impressions, but some bear compositions of scratched lines. Most vessels are flat-based. The rims are collar-shaped, bent, sharpened. The assemblage of Kalmius finds close analogies among the Neolithic and Early Eneolithic sites of the South Russian Plain.

Key words: Mariupol burial ground, Neolithic layer of Kalmius settlement, Northeastern Azov Sea region, Neolithic, ceramic assemblage.

\section{НОВОЕ НЕОЛИТИЧЕСКОЕ ПОСЕЛЕНИЕ В МАРИУПОЛЕ И ЕГО МЕСТО В СИСТЕМЕ СИНХРОННЫХ ПАМЯТНИКОВ}

\author{
Владимир Николаевич Горбов \\ Донецкий республиканский краеведческий музей, г. Донецк, Украина
}

\section{Александр Викторович Колесник}

Донецкий национальный университет, г. Донецк, Украина

\begin{abstract}
Аннотация. Поселение Кальмиус в Северо-Восточном Приазовье находится на левом берегу р. Кальмиус в историческом центре г. Мариуполя. Оно является многослойным и содержит культурные слои от неолитической эпохи до современности. Неолитический культурный слой претерпел значительную постгенетическую деформацию. Культурные остатки неолитической эпохи залегают в ископаемой черноземной почве на значительной глубине. В неолитическом слое найдены многочисленные кремневые изделия, обломки костей животных, обломки керамики, преимущественно мелкие фрагменты. Статья посвящена описанию керамического комплекса неолитического слоя стоянки Кальмиус, обоснованию связи поселения и Мариупольского могильника, сравнению материалов поселения с синхронными комплексами Северного Приазовья и Нижнего Дона. Детализируется сравнительный анализ опубликованных ранее кремневых изде-
\end{abstract}


лий поселения и кремневого комплекса Мариупольского могильника. Общая для поселения и могильника кремневая индустрия основана на небольших по размеру и средних отжимных пластинах. Близкими или идентичными являются типы микролитов, наконечники с двусторонней обработкой и другие изделия. Вероятно, время существования Мариупольского могильника было шире времени существования неолитического слоя поселения Кальмиус. Различия в керамическом тесте позволяют реконструировать две технологии изготовления сосудов. Основная часть фрагментов керамики украшена оттисками зубчатого штампа. Часть сосудов декорирована композициями из прочерченных линий. Основная часть сосудов имела плоское дно. Среди венчиков встречаются воротничковые формы, экземпляры с отогнутым бортиком, с заостренным профилем. Комплекс материальных остатков неолитического слоя поселения Кальмиус находит близкие аналогии среди неолитических и ранних энеолитических памятников юга Русской равнины.

Ключевые слова: Мариупольский могильник, неолитический слой поселения Кальмиус, Северо-Восточное Приазовье, неолит, керамический комплекс.

\section{Введение}

В 2010 г. Приазовская археологическая экспедиция (руководитель - В.Н. Горбов) совместно с Мариупольским краеведческим музеем приступила к исследованиям в черте г. Мариуполя на территории бывшей крепости запорожских казаков Кальмиус. Памятник находится на мысу высокого правого берега р. Кальмиус (рис. 1). В результате первых раскопок стало ясно, что памятник многослойный и включает разнообразные культурные остатки Нового времени, Средних веков и бронзового века [3]. Общая мощность слоя в центральной части памятника достигала 1,9 м. В 2012 г. на площади 42 кв. м был исследован северный участок памятника. Здесь под культурным слоем бронзового века был выявлен и исследован частично разрушенный слой неолитического поселения. В 2014 г. на юго-восточной оконечности памятника раскопом площадью 24 кв. м был изучен участок с аналогичной культурной колонкой мощностью до 2,8 м. В 2015 г. был исследован юго-западный участок памятника, однако слой неолитического времени здесь не сохранился. Таким образом, культурные остатки неолитического времени изучены в двух раскопах общей площадью 66 кв. м.

\section{Характеристика горизонта с неолитическими культурными остатками}

Культурные остатки неолитического возраста залегали в ископаемой почве. Уровень современной поверхности площадки почти го-

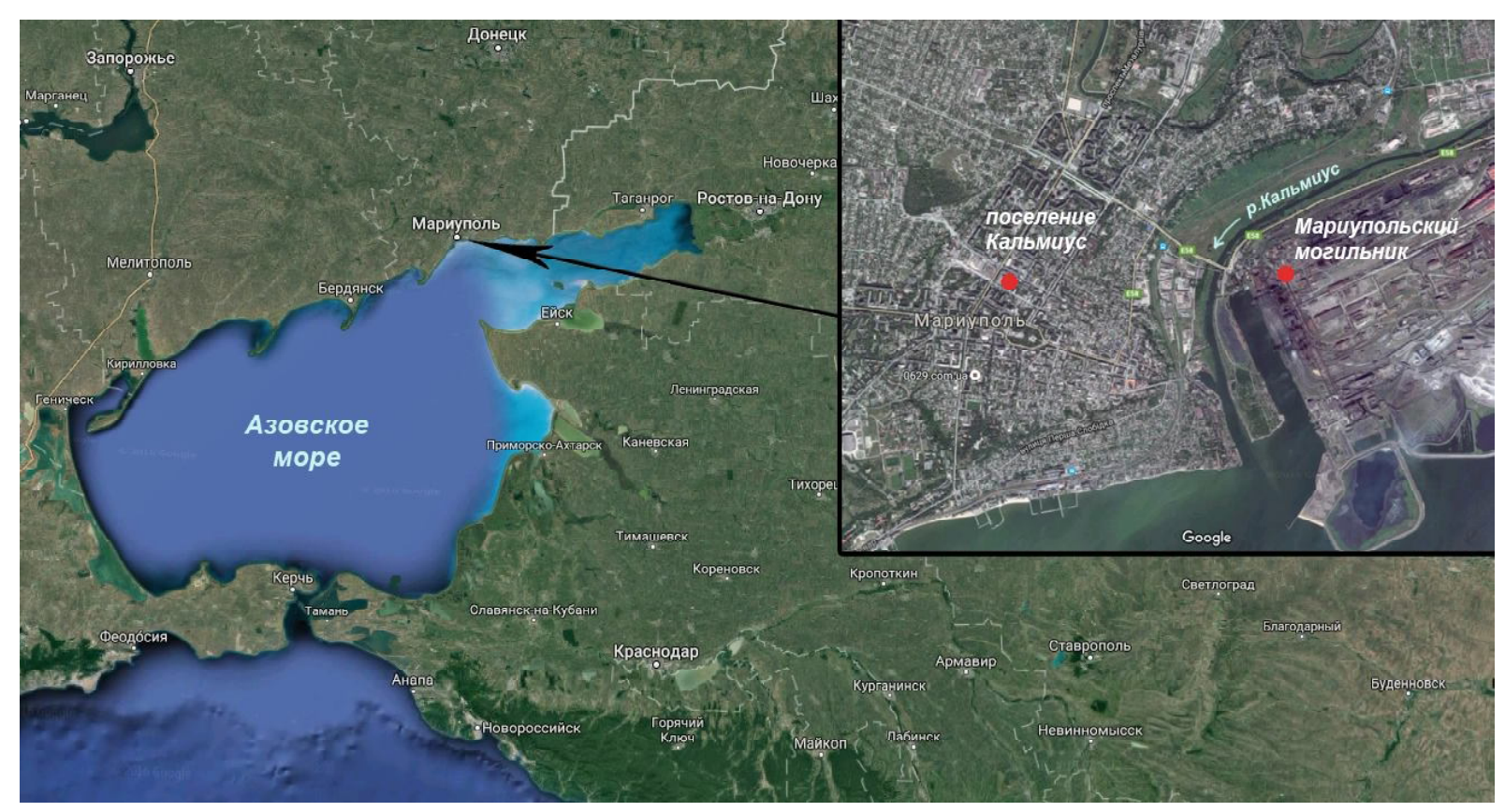

Рис. 1. Карта-схема расположения Мариупольского могильника и поселения Кальмиус 
ризонтальный и в пределах археологического памятника существенно не меняется. При этом ископаемая гумусированная почва в разрезе залегает в целом наклонно в сторону долины реки судя по разрезу по линии север - юг. На северном участке памятника кровля почвы залегает почти горизонтально, на юго-восточном участке заметно отчетливое падение вниз по склону древней террасы. Соответственно, мощность почвы увеличивается в том же направлении. Песчаная гумусированная почва имеет мощность до 0,7 м и практически по всей толще включает разрозненные культурные остатки эпохи неолита. Отмечена заметная концентрация находок в средней части почвы в пределах 30-40-сантиметрового горизонта. На северном участке местонахождения наибольшая насыщенность находками прослежена на глубине 1,3-1,7 м, на юго-восточном - на глубине 1,92,3 м (см. таблицу). Возможно, этот уровень соответствует первоначальной стратиграфической позиции культурного слоя. В степной зоне Русской равнины культурные слои памятников каменного века претерпевали существенную постгенетическую деформацию. В результате деструкции слоя артефакты активно «мигрировали» по профилю почвы во время ее образования и после завершения цикла седиментации.

Характер залегания неолитических культурных остатков неодинаков на различных участках памятника. На юго-восточном участке артефакты распределены в плане почти равномерно, на северном участке выявлены отдельные скопления в виде небольших зон повышенной концентрации находок (до 1 кв. м). Возможно, на северном участке нео- литический культурный слой испытал деструкцию, связанную в основном с вертикальным переносом предметов в почвенном субстрате. Как правило, перемещение предметов в почвенном профиле по вертикали связано с криогенными процессами. На склоновом юговосточном участке сохранились остатки слоя, значительно разрушенные процессами горизонтального делювиального сноса. Этому не противоречит система связей между деталями небольшого складня, происходящего из юго-восточного раскопа: совмещаемые фрагменты одной из пластин растянуты вниз по склону. Таким образом, неолитический культурный слой поселения Кальмиус в значительной степени разрушен процессами почвообразования и сохранился в виде горизонта культурных остатков. При разборке горизонта с культурными остатками неолитического времени не удалось зафиксировать какие-либо структурные элементы культурного слоя с первоначальным планиграфическим контекстом. Отдельные находки неолитического облика встречены за пределами гумусового горизонта почвы. Подобные литологические структуры, вмещающие культурные остатки каменного века, представляют большой интерес в рамках теории культурного слоя.

Неолитические культурные остатки являются гомогенными, не содержат инородной примеси. Между горизонтом с культурными остатками неолитического возраста и культурным слоем бронзового века имеется выраженная стерильная прослойка. Расчистка почвенного горизонта с неолитическими культурными остатками осуществлялась ножами. Материал груп-

Поселение Кальмиус. Распределение неолитических кремней и керамики по глубинам

\begin{tabular}{|c|c|c|c|c|c|c|c|c|c|}
\hline \multicolumn{10}{|c|}{ Северный участок (2012 г.) } \\
\hline \multirow[t]{3}{*}{$0,8-0,9 \mathrm{M}$} & $1 \mathrm{M}$ & $1,1 \mathrm{M}$ & $1,2 \mathrm{M}$ & $1,3 \mathrm{~m}$ & $1,4 \mathrm{M}$ & $1,5 \mathrm{M}$ & $1,6 \mathrm{M}$ & $1,7 \mathrm{M}$ & $1,8 \mathrm{M}$ \\
\hline & $8 / 46^{*}$ & $3 / 3$ & $45 / 64$ & $199 / 96$ & $341 / 55$ & $494 / 49$ & $389 / 95$ & $347 / 43$ & $181 / 2$ \\
\hline & 54 & 6 & 109 & 295 & 396 & 549 & 484 & 390 & 183 \\
\hline & & & & & & & & \multicolumn{2}{|c|}{$\begin{array}{r}\text { Кремень - } 2007 \\
\text { * Керамика - } 453\end{array}$} \\
\hline & & & & & & & & \multicolumn{2}{|c|}{ Итого: 2460} \\
\hline \multicolumn{10}{|c|}{ Юго-восточный участок (2014 г.) } \\
\hline $1,5-1,6 \mathrm{M}$ & $1,7 \mathrm{M}$ & $1,8 \mathrm{M}$ & $1,9 \mathrm{M}$ & $2 \mathrm{M}$ & $2,1 \mathrm{M}$ & $2,2 \mathrm{M}$ & $2,3 \mathrm{M}$ & $2,4 \mathrm{M}$ & $2,5 \mathrm{M}$ \\
\hline $12 / 12$ & $15 / 3 *$ & $76 / 33$ & $129 / 63$ & $355 / 115$ & $220 / 106$ & $104 / 66$ & $170 / 52$ & $56 / 34$ & $4 / 2$ \\
\hline 24 & 18 & 109 & 192 & 471 & 326 & 170 & 222 & 90 & 6 \\
\hline & & & & & & & & \multicolumn{2}{|c|}{$\begin{array}{r}\text { Кремень - } 1141 \\
* \text { Кералика }-485 \\
\end{array}$} \\
\hline & & & & & & & & \multicolumn{2}{|c|}{ Итого: 1626} \\
\hline
\end{tabular}


пировался по условным горизонтам $(10 \mathrm{~cm})$ в пределах раскопочных квадратов $2 \times 2$ м.

\section{Общая характеристика коллекции}

Как неоднократно отмечалось в предшествующих публикациях, в ходе разборки горизонта культурных остатков неолитического времени собрана значительная коллекция кремневых изделий, фрагментов керамики, костей животных, изделий из мягких пород камня, костяных орудий. Находки включая кости животных отличаются хорошей сохранностью. Особенностью коллекции является доминирование мелкой фракции керамических фрагментов, кремневых чешуек и мелких осколков костей животных. В целом это соответствует модели интенсивной переработки пищевых и минеральных ресурсов.

В двух опубликованных ранее статьях детально проанализированы неолитические кремневые изделия и предметы из мягких пород камня [5; 7].

Для более полного понимания неолитического комплекса поселения Кальмиус необходимо дать суммарную характеристику керамики, детализировать сравнение данного поселенческого комплекса с Мариупольским могильником, прежде всего, на основании изделий из камня, обосновать параллели с нео-энеолитическими памятниками юга Русской равнины. Эти задачи являются основными для данной публикации.

\section{Керамический комплекс}

При расчистке неолитического слоя собрана весьма представительная коллекция древней керамики. Всего найдено 938 образцов, однако в подавляющем большинстве это мелкие неопределимые фрагменты. Значительная фрагментация сосудов, многочисленные следы ремонтов в виде просверленных биконических отверстий (см. рис. 2, 1-2, 4, б) свидетельствуют о выраженной изношенности керамической посуды. Такое состояние керамического комплекса хорошо согласуется с общей характеристикой кремневой индустрии, ориентированной на максимально полное использование каменного сырья. Кости животных также представлены преимущественно мелкими обломками. Возможно, доминирование мел- кой фракции фрагментов сосудов связано не только с общей стратегией интенсивного использования ресурсов, но и с особенностями формирования и постдепозиционного разрушения культурного слоя памятника.

Несмотря на преобладание мелких неорнаментированных обломков, коллекция керамики дает ясное представление о технологии изготовления сосудов, типах орнамента и способах их нанесения.

По керамическому тесту выделяются по крайней мере два варианта изготовления посуды. Первая (подавляющая) часть фрагментов имеет в тесте пустоты от выгоревшей шерсти и волос животных. Вторая небольшая группа фрагментов сосудов изготовлена из глины с большим количеством песка. В керамическом тесте также отмечена примесь слюды, неопределенной органики. Обжиг сосудов двух технологических групп достаточно качественный: черепок в изломе имеет темно-серый, черный или красно-бурый цвет, только очень небольшая часть фрагментов двухцветная (черный и серый). Внешняя и внутренняя поверхность посуды обрабатывалась различными гончарными орудиями. Использование зубчатых штампов приводило к появлению на поверхности разнонаправленных следов. Отделка поверхности другой части сосудов осуществлялась какими-то гладкими орудиями, что приводило к появлению системы горизонтальных заглаженных следов. Характер последующей орнаментации не связан строго со способом подготовки поверхности.

Между керамикой, происходящей из северного и юго-восточного участков поселения, заметны некоторые отличия в стилях орнаментации, поэтому охарактеризуем ее раздельно по раскопам.

Коллекция керамики из северного участка памятника (453 фрагмента), весьма выразительна. Черепок достаточно плотный, цвет поверхности красный, коричневый, реже - приближающийся к черному. Эти признаки отражают качественный костровый обжиг. Все фрагменты венчиков сосудов (за исключением одного) орнаментированы. Орнамент наносился зубчатым штампом, реже-прочерченными линиями. Судя по реконструируемым крупным фрагментам основная часть сосудов относилась к категории сложно профилированных горшков и имела плос- 


\section{АРХЕОЛОГИЯ}
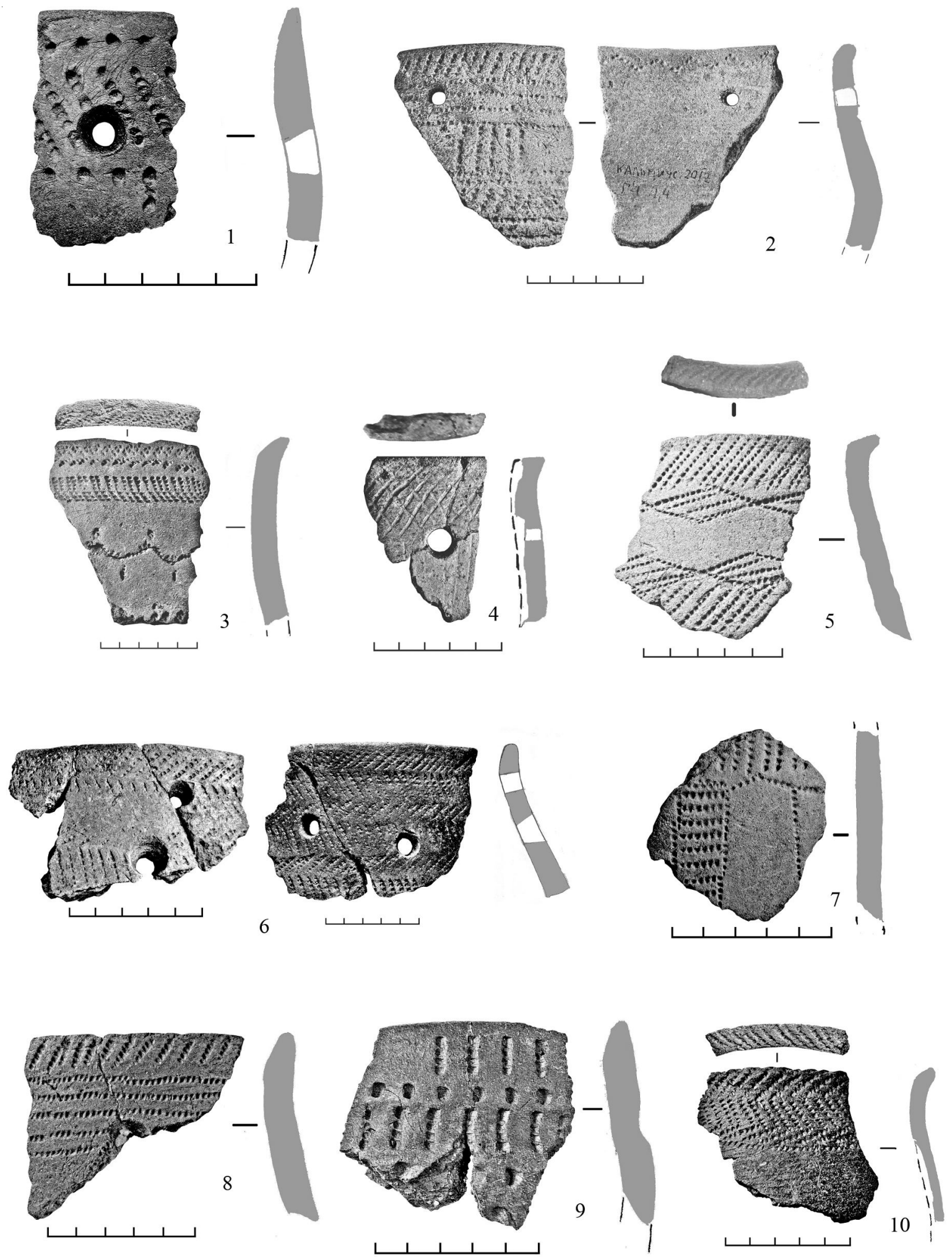

Рис. 2. Поселение Кальмиус. Керамика из неолитического слоя (фото)

кое дно. Преобладают сосуды с плавной профилировкой, выраженной шейкой, раздутым туловом. Они орнаментированы различными композициями зубчатого штампа, в том числе в виде ломаных линий (рис. 2, 6, 10), реже - в виде вертикальной елочки (см. рис. 3, б). Встречены композиции оттисков штампа с «резервной» зоной между ними (рис. 2, 3, 5, 7). 
Новое неолитическое поселение в Мариуполе и его место в системе синхронных памятников
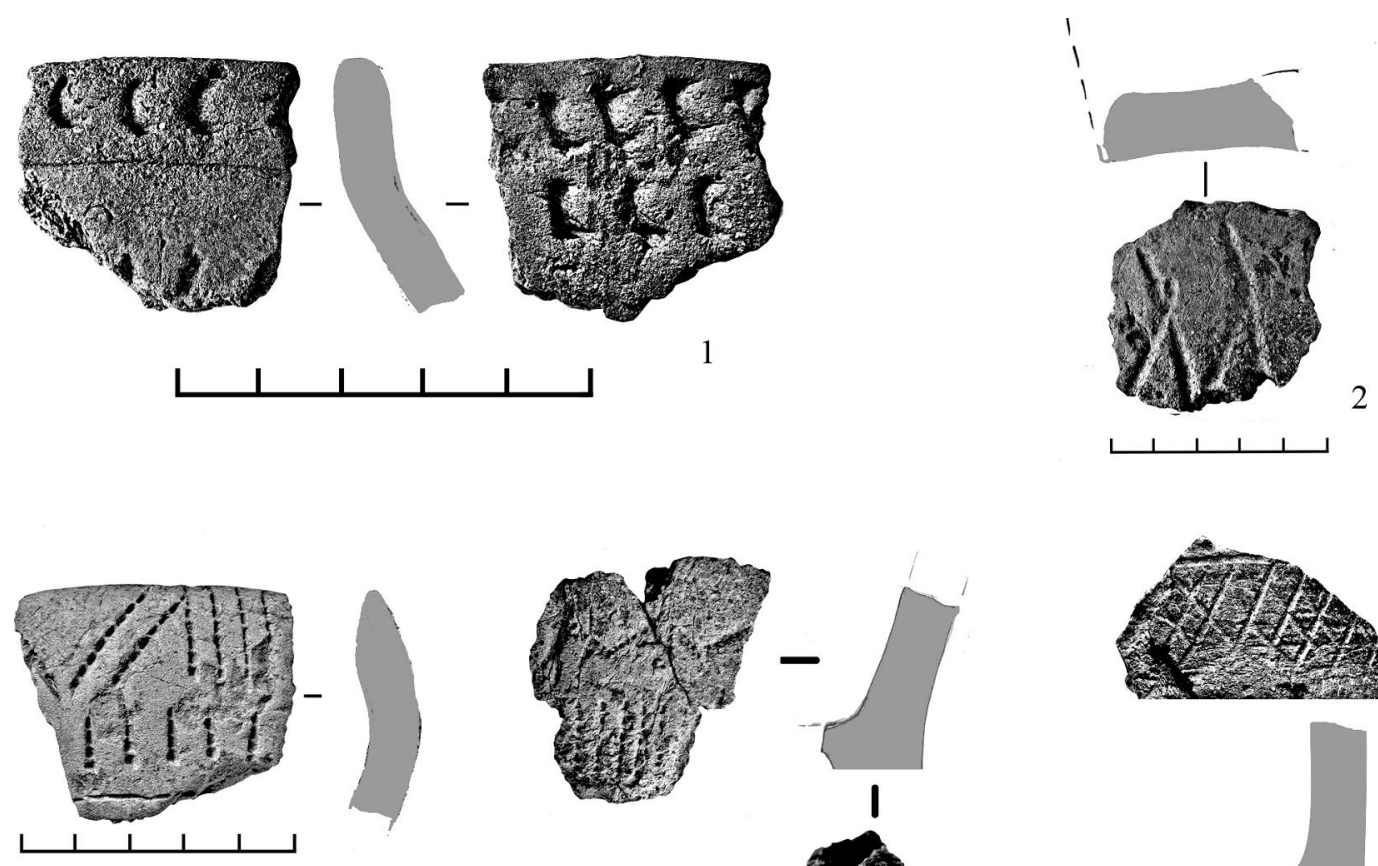

3
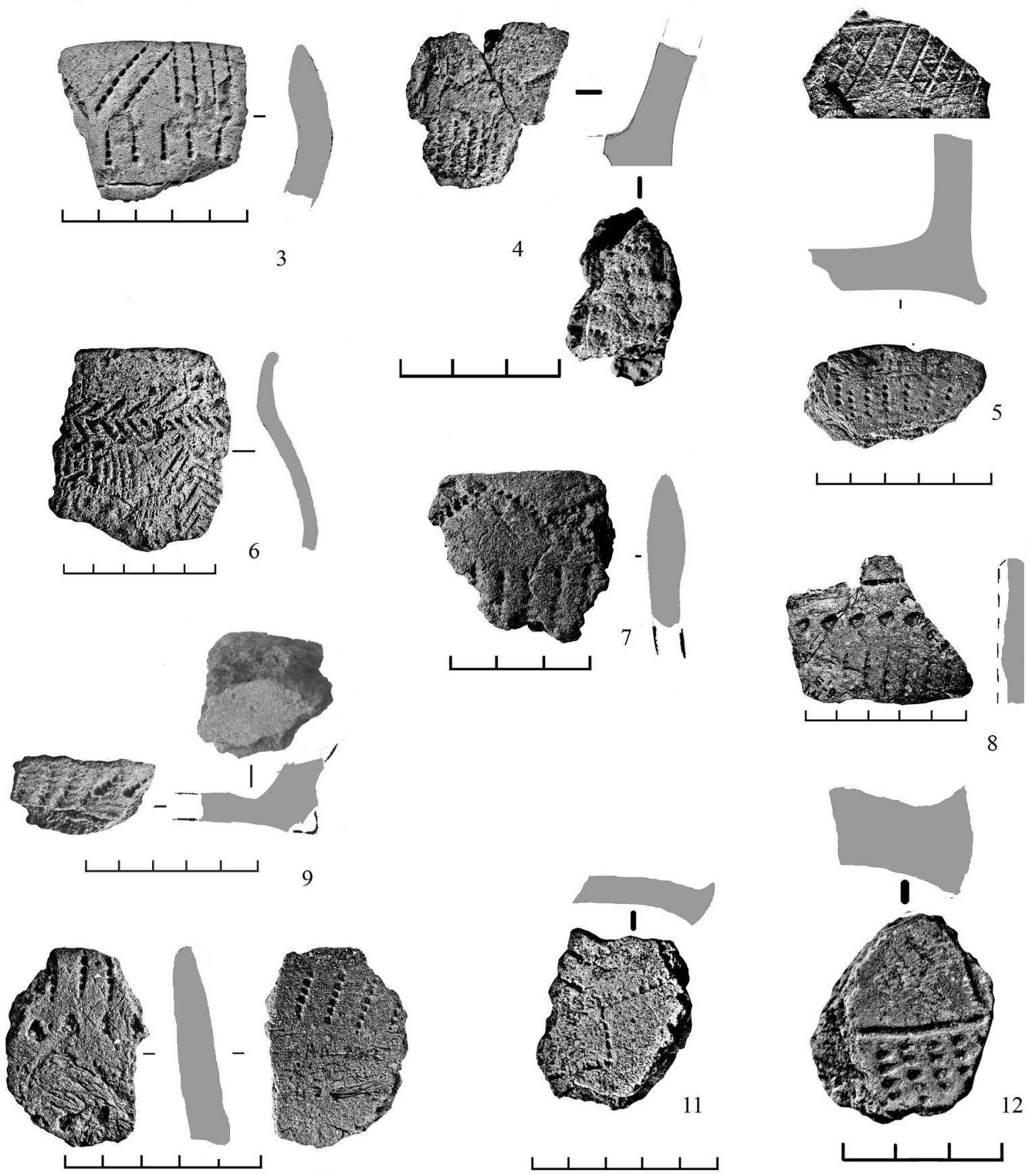

Рис. 3. Поселение Кальмиус. Керамика из неолитического слоя (фото) 
Наибольший интерес представляют сосуды с косо срезанным внутрь краем венчика, орнаментированным зубчатым штампом (см. рис. 2, 3, 5, 10). Встречается орнамент на внутренней части венчика (см. рис. 2, 2; 3 , 10). Это характерные признаки I-А периода азово-днепровской культуры [8, с. 40]. Показателен фрагмент сосуда, орнаментированный косыми оттисками штампа и двумя рядами горизонтально расположенных ромбов или треугольников, стыкующихся вершинами, с «резервной зоной» между ними; косо срезанный край венчика орнаментирован оттисками зубчатого штампа (см. рис. 2, 5). Близкая аналогия как по форме, так и по орнаментации отмечена на сосуде, происходящем из нижнего слоя пос. Семеновка, относящегося к I-A периоду азово-днепровской культуры $[9$, рис. 62 , 36]. Наибольший интерес представляет керамика синкретического облика, отражающая контакты трех культур. Например, сочетание в орнаментации одного сосуда (см. рис. 4,3 ) оттисков сегментовидного штампа, характерного для азово-днепровской культуры, с вдавлениями, характерными для поздней сурской культуры $[10$, рис. 2]. Ряды вдавлений в сочетании с оттисками сегментовидного штампа встречаются на сосудах округлых форм (см. рис. 2,9 ), близких к нижне-донской культуре $[9$, рис. $71,5,8]$. Большой интерес представляет фрагмент сосуда со стенками, сужающимися книзу и расширяющимися в придонной части, орнаментированной зубчатым штампом (см. рис. 4, 2). Практически аналогичный фрагмент найден во втором горизонте поселения Раздорское [10, рис. 4, 8], отнесенного к первому этапу нижне-донской культуры $[9$, рис. 72,5$]$. Найдено также несколько фрагментов нижних частей сосудов с орнаментированной придонной частью, при этом профиль стенки, как правило, вогнутый (см. рис. $3,4,5,9,11,12)$. Подобная формовка дна фиксируется на памятниках, расположенных в зоне контакта азово-днепровской и днепро-донецкой $[8$, рис. 4,4$]$ или азово-днепровской и буго-днестровской [16, рис. 2] культур. Сочетание орнаментированной нижней части сосудов с вогнутым дном (см. рис. 3,5 ), возможно, является особенностью местной керамической традиции. Для северного участка (раскоп 2012 г.) преимущественно была харак- терна керамика I-A периода азово-днепровской культуры (по определению Н.С. Котовой), которая отличается от керамики юго-восточного участка орнаментальными композициями и способом их нанесения.

В слое найден штамп для орнаментации керамики, у которого три зубца сохранились, один отломан (см. рис. 4,1$)$. Он сделан из расколотой вдоль трубчатой кости мелкого копытного, что и определило сегментовидную форму рабочей части и ее оттисков. Оттиски подобных штампов зафиксированы на керамике с поселения.

Керамика из юго-восточного участка памятника (485 обломков) представлена фрагментами таких же по конструкции сосудов, преимущественно плоскодонных горшков с профилированным венчиком. Для керамики юго-восточного участка характерно большее разнообразие орнаментов, которые отличаются как по формам и размерам рабочей поверхности, так и по выбору сырья. Использовались разнообразные зубчатые штампы, тонкие острия, а также челюсти животных семейства собачьих. Выделяются композиции в виде треугольников (см. рис. $5,8,10$; рис. 6,3 ), комбинаций из вертикальных и горизонтальных поясов (см. рис. 5, 3, 6), зубчатых штампов и вдавлений (см. рис. 5, 4-5, 9). Выделяются геометрические композиции (см. рис. $6,2,7)$. Редко наносился прочерченный орнамент в виде горизонтальных линий (см. рис. 6, 5), треугольника с сетчатым заполнением (см. рис. 6,1 ). Посуда часто украшалась орнаментальными лентами, заполненными мелким зубчатым штампом. Подобные аналогии встречаются в керамике, происходящей из поселения Ракушечный Яр на Нижнем Дону. Использование орнаментальных лент жителями поселения Кальмиус имело местные особенности, которые проявлялись в своеобразии композиционных решений. Это, например, сочетание орнаментальных лент мелкозубчатого штампа с отпечатками крупнозубчатого на одном сосуде (см. рис. 5,10 ) или их нанесение на внешнюю поверхность вогнутого дна (см. рис. 6, 4). Иногда орнаментальные ленты ограничивают «резервную зону», которая встречается в композициях азово-днепровской культуры, но на керамике данного памятника в центре «зоны» также мог располагаться и дополнительный элемент, например меандр (см. рис. 5, 1). 
Новое неолитическое поселение в Мариуполе и его место в системе синхронных памятников
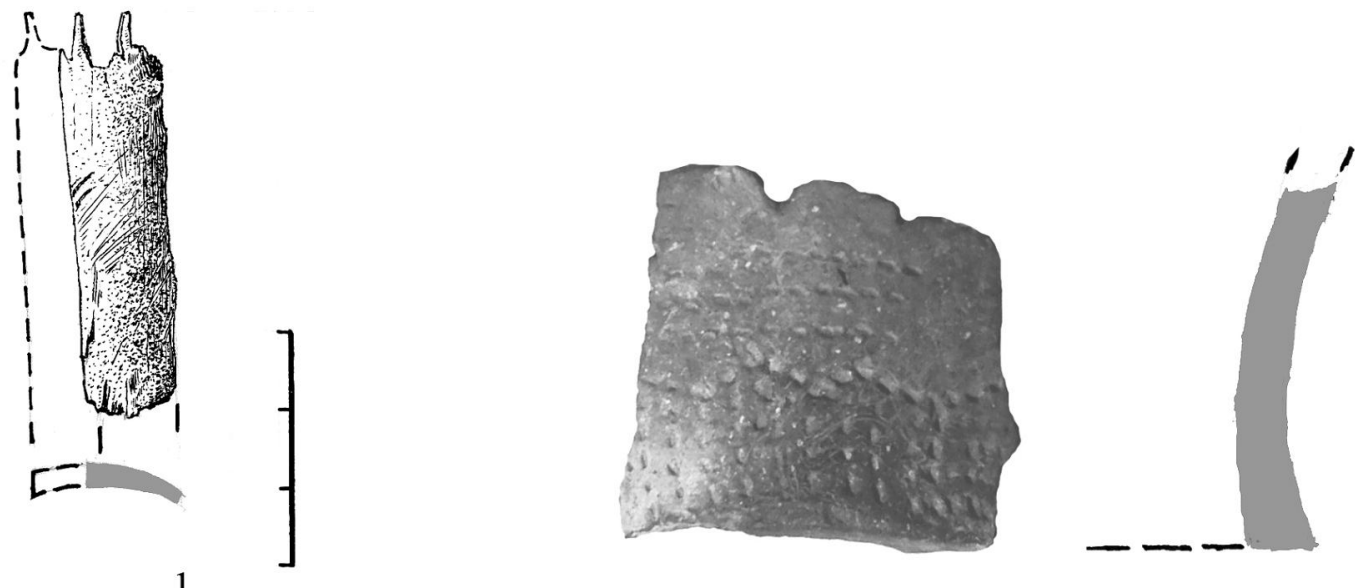

1

2

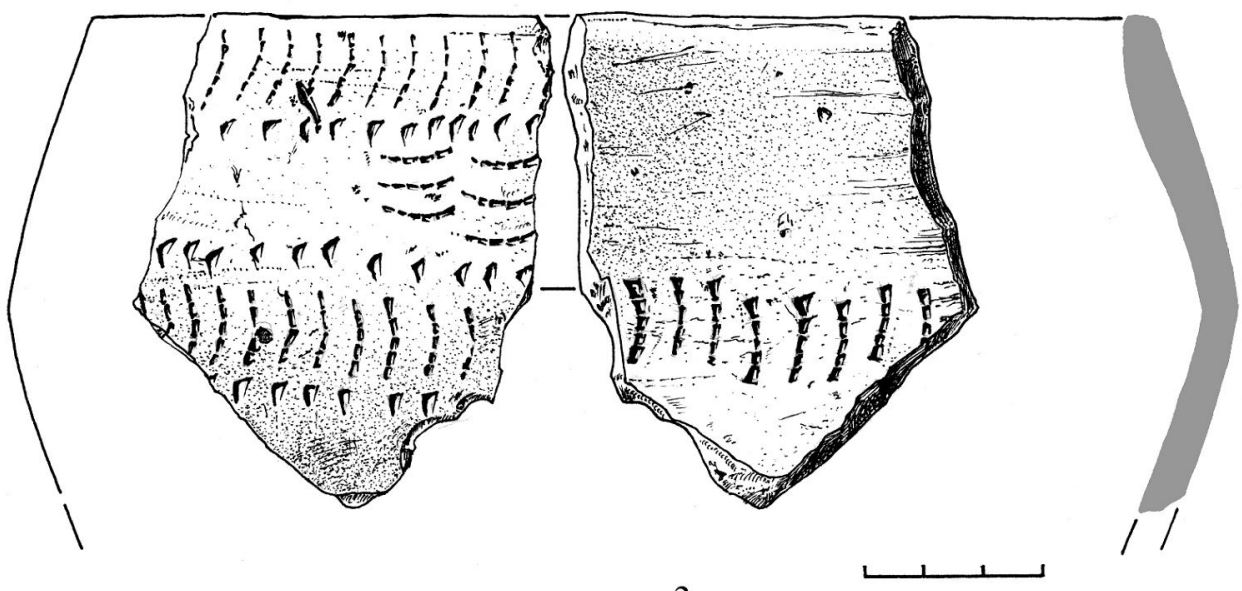

3

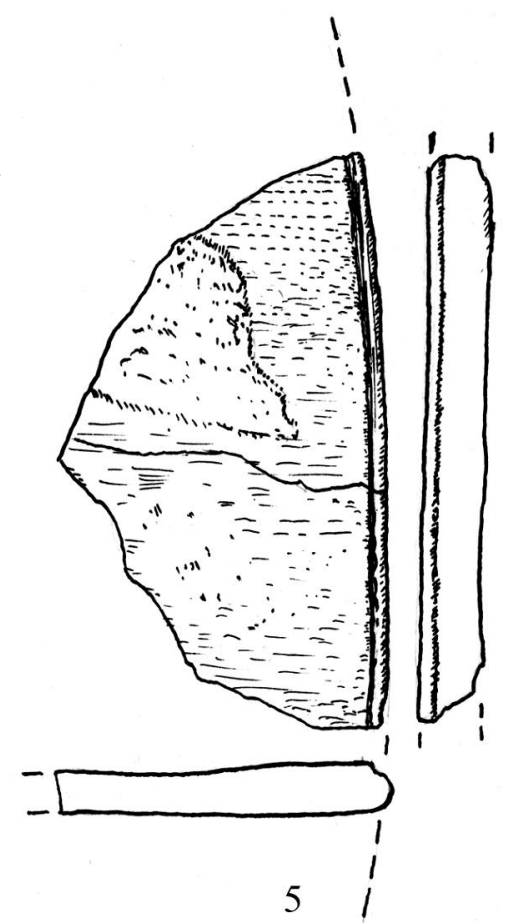

Рис. 4. Поселение Кальмиус. Зубчатый штамп (1), керамика (2-3) и обломки обработанных плиток (4-5) 

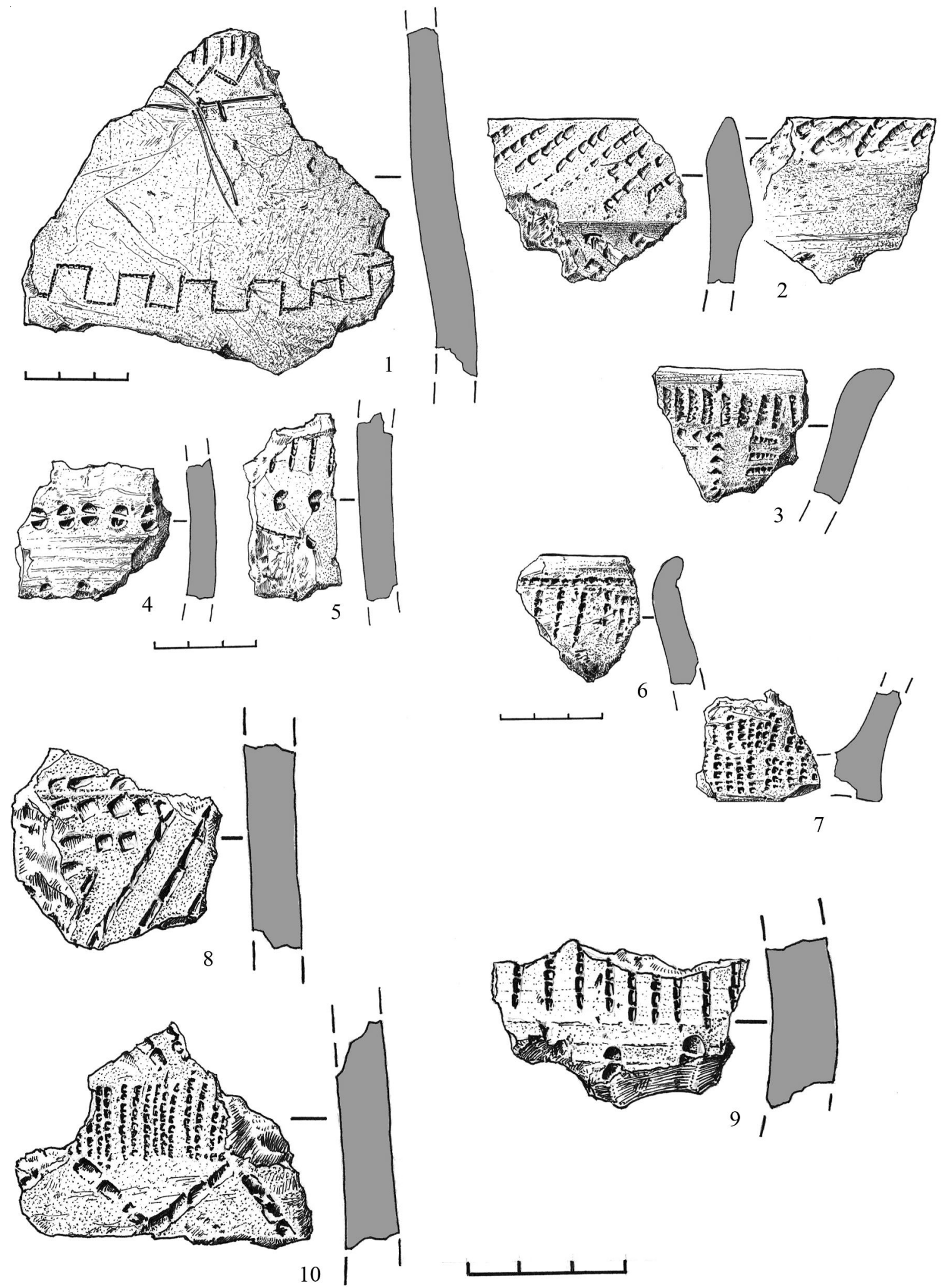

Рис. 5. Поселение Кальмиус. Керамика из неолитического слоя 
Новое неолитическое поселение в Мариуполе и его место в системе синхронных памятников

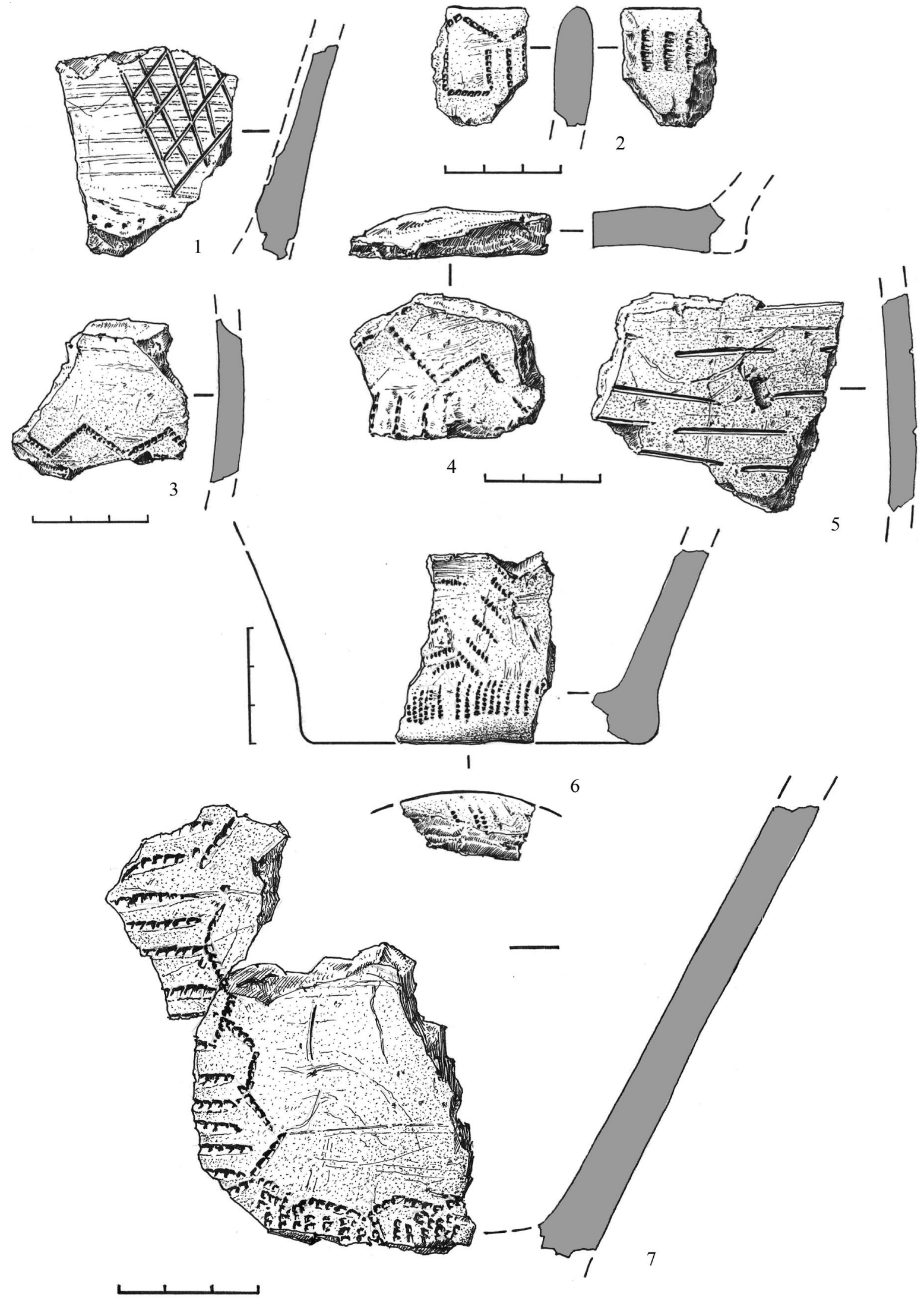

Рис. 6. Поселение Кальмиус. Керамика из неолитического слоя 
На керамике северного и юго-восточного участков заметны различия в расположении штампов по отношению к поверхности сосудов в процессе орнаментации. В первом случае доминируют фрагменты стенок, на которых штамп располагался вертикально, во втором случае заметно чаще встречаются штампы, нанесенные под тупым углом.

Следует отметить, что если для керамики северного участка характерны доминирующие признаки I-A периода азово-днепровской культуры, то для юго-восточного - I периода нижне-донской культуры.

\section{Сравнительный анализ комплекса}

Сравнительный анализ материалов поселения логично проводить с близкими по времени комплексами в порядке их удаления от поселения Кальмиус. Такой алгоритм анализа приводит нас прежде всего к знаменитому Мариупольскому могильнику, расположенному на левом берегу реки. По данным Н.Е. Макаренко, могильник находился в двух километрах на восток от рыночной площади г. Мариуполя [12, с. 7].

Н.Е. Макаренко исследовал первый из памятников, которые впоследствии были определены как могильники мариупольского типа [15]. Изучение неолитических могильников Поднепровья, близких по обряду захоронения, позволило А.Д. Столяру сделать вывод о том, что Мариупольский могильник являлся «наиболее выразительным и значительным из них» [13, с. 16]. По мнению Н.С. Котовой, что «инвентарь Мариупольского могильника в целом и в каждом его инвентарном погребении по своему многообразию и исключительности не имеет равных в Поднепровье» [9, с. 20].

Вопрос о поселке людей, оставивших Мариупольский могильник, был поставлен самим Н.Е. Макаренко. Исследователь допускал, что одиннадцать едва заметных ямок на западной оконечности мыса с могильником могли быть остатками такого поселения, однако этот участок был полностью уничтожен строительными работами весной 1931 г. [12, с. 23].

Сравнительный анализ комплексов предметов из Мариупольского могильника и неолитического слоя поселения Кальмиус позволяет вполне обоснованно проводить паралле- ли между ними. В первую очередь это касается кремневых изделий.

Как известно, в могилах Мариупольского некрополя найдено 181 кремневое изделие, еще около 20 кремней происходят из заполнения могил [12]. В погребения помещали специально отобранные кремневые изделия, которые функционировали в «живой культуре» на момент совершения погребального обряда. Кремневые изделия встречены в 40 могилах $(32,5 \%$ погребений в траншейной части могильника), как женских, так и мужских. Наиболее значимы компактные скопления кремневых орудий, трактуемые как индивидуальные «ранцевые наборы» разного типа всего их 9. Два скопления являются остатками колчанных наборов; в одном случае сохранились остатки крупных пазовых наконечников в виде наборных лезвий из ретушированных пластин, в другом случае в роли трансверсальных наконечников выступали трапеции разных типов [6]. Типологическое ядро коллекции кремневых изделий из могильника составляют клиновидные топоры-тесла, трапеции со струганой спинкой, крупный треугольный наконечник стрелы с двусторонней обработкой, мелкие и средние по размеру отжимные пластины с ретушью и без нее. Присутствуют концевые скребки, пластинки с поперечным усечением. Технологическая база кремневой индустрии была основана на эксплуатации средних и небольших отжимных призматических нуклеусов и технике двусторонней оббивки. Использовался преимущественно принесенный со стороны меловой кремень хорошего качества.

Кремневый инвентарь неолитического слоя поселения Кальмиус является гомогенным; изделия из двух раскопанных участков относятся к одной индустрии. Всего обнаружено 3309 кремневых изделий. Коллекция 2012 г. содержит 2122 кремня (2 007 изделий найдены в слое, 115 найдены при просеивании), коллекция 2014 г. включает 1187 кремневых изделий (1 141 кремень найден в слое, 46 найдены при просеивании). В технологическом плане индустрия основана на пластинах, отжатых от призматических нуклеусов небольших и средних размеров, а также технике двусторонней оббивки. Серийно представлены различные трапеции, в том 
числе со струганой спинкой, ретушированные и усеченные пластины, округлые скребки, специфические негеометрические микролиты. Найдены наконечники с двусторонней обработкой, следы изготовления крупных орудий-бифасов. Специфический типологический оттенок кремневой индустрии придают миниатюрные листовидные скребки-острия, специфические сегменты и миниатюрные овальные скребки [5, рис. 1, 16$20 ; 7$, рис. 2, 15-20]. Типология кремневых изделий из поселения гораздо разнообразнее материалов могильника, но имеет те же базовые характеристики. Микролитизм кремневой индустрии поселения объясняется значительной глубиной переработки каменного сырья. Интенсивная подправка кремневых орудий неизбежно вела к росту их типологического многообразия. При этом ведущие типы кремневых изделий поселения и могильника являются общими. В могильник попадали отобранные вещи, поэтому в материалах могильника нет сработанных до предела негеометрических микролитов, характерных для кремневой коллекции поселения. Сравнительная таблица показывает совпадение основных категорий кремневого инвентаря (см. рис. 7). Кремневая индустрия могильника фактически является фракцией из наиболее эффектных орудий на начальной и средней стадии сработанности, искусственно извлеченной из кремневой индустрии поселения.

Говоря о близости поселения и могильника, важно отметить наличие в двух комплексах похожих костяных зубчатых штампов для орнаментации керамики. Зубчатый штамп из трубчатой кости животного был найден в раскопе 2012 года. Похожий зубчатый штамп в виде тщательно отделанной плоской подвески прямоугольной формы происходит из могилы XVI [12, табл. XII, 63].

К одному классу изделий относятся также специфические тонкие шлифованные каменные плитки. Эффектная плитка из погребения Мариупольского могильника сопровождалась каменным растиральником с заглаженной поверхностью [12, табл. XVI]. В слое поселения Кальмиус помимо двух шлифованных плиток из песчаника [7, рис. 4 , 2-3] найдены фрагменты сланцевых плиток со следами обработки (рис. 4, 4-5). Видимо, эти относительно тонкие шлифованные плитки предназначались для каких-то неутилитарных целей.

Сравнивать керамику поселения и могильника сложно. Единственный фрагмент сосуда из заполнения могильника аналогичен подобным образцам из поселения. Фрагмент донышка лепного сосуда из заполнения могильника украшен характерным отпечатком зубчатого штампа [12, рис. 91, 411]. Орнамент в виде косо расположенных линий концентрируется в нижней части сосуда.

В целом есть веские основания относить неолитический слой поселения Кальмиус и Мариупольский могильник к одному культурному комплексу. Скорее всего, могильник был некрополем обитателей поселка. Расположение долговременного поселения на правом берегу реки, а могильника на левом берегу, за реальной и условной границей места обитания общины, является классическим примером организации сакрального пространства людей неолитической эпохи.

Современное представление о культурном комплексе мариупольского типа в значительной степени базируется на работе И.Б. Васильева и А.Т. Синюка 1985 г. [2, с. 31]. Один из восьми признаков мариупольской историкокультурной области касается крупных ножевидных пластин. Вместе с тем в эталонном памятнике - самом Мариупольском могильнике - средняя длина целых пластин относительно небольшая; в достоверных случаях отмечена длина $38,57,57,58,60,75,90,92$, 122, 140 и 164 мм. Средняя математическая длина целых пластин - 87 мм. Три целых образца пластин из раскопа 2014 г. на поселении имеют длину 56, 65 и 87 мм, при этом сохранились сечения более крупных пластин длиной до 150-160 мм; длина наиболее крупного орудия из пластины составляет 88 мм [7, рис. 3,46$]$. В целом кремневая индустрия из поселения и Мариупольского могильника не является крупнопластинчатой в отличие от более поздних комплексов «новоданиловского» типа. Для последних характерны крупные (до 180-200 мм) отжимные кремневые пластины из качественного «донецкого» мелового кремня. Морфология этих пластин явно указывает на особую технику отжима. 


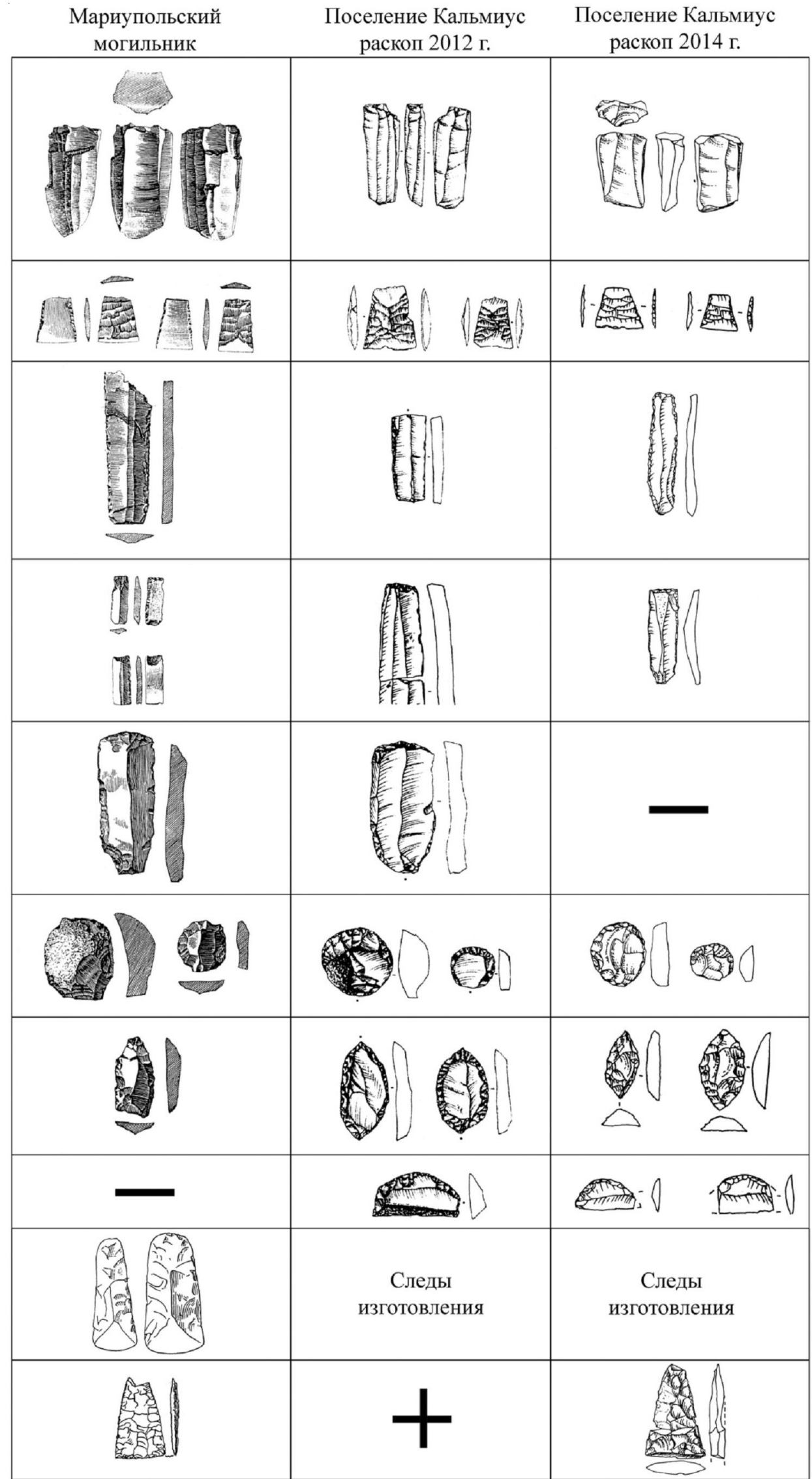

Рис. 7. Кремневые изделия Мариупольского могильника и поселения Кальмиус 
Клиновидные топоры из кремня и мягких пород камня, действительно, серийно встречаются в комплексах мариупольского типа, так же как и трапеции со струганой спинкой, треугольные наконечники с двусторонней обработкой. Эти клиновидные топоры хорошо вписываются в типологический ряд топоров нео-энеолита Восточной Европы, занимают позицию перед шлифованными треугольнопараболическими топорами, обычными для памятников новоданиловского типа.

Листовидные скребки-острия, специфические сегменты и миниатюрные овальные скребки находят отдельные аналогии в комплексах сурской культуры $[4 ; 12]$.

Более обоснованные параллели дает анализ керамики поселения.

Содержащий керамику неолитический слой исследован также на поселении Раздольное в среднем течении р. Кальмиус. Расстояние между поселениями в Мариуполе и в Раздольном около 60 км по течению реки. Керамический комплекс поселения в Раздольном отнесен ко второму этапу нижнедонской культуры, при этом в нем прослеживается влияние традиций сурской культуры $[9$, с. $27 ; 10$, с. 19].

Как известно, Н.С. Котова отнесла Мариупольский могильник по целому ряду признаков к нижне-донской культуре [9, с. 26]. В соответствии с предложенной ею культурно-хронологической схемой неолитический слой поселения Кальмиус следует синхронизировать как с первым этапом этой культуры, так и с вытянутыми на спине неокрашенными погребениями Мариупольского могильника [9, с. 27].

Азово-днепровская и нижне-донская культуры отнесены Н.С. Котовой вслед за И.Б. Васильевым к Мариупольской культурно-исторической общности [9, с. 24]. Необходимо сделать некоторое уточнение. Могильник у с. Съезжее [1] можно синхронизировать только с поздними этапами указанных культур. Вероятно, первые периоды азово-днепровской и нижне-донской культур следует выделить в ранний этап Мариупольской культурно-исторической общности, которая только на позднем (окончательном) этапе занимает территориальные границы, определенные И.Б. Васильевым от Урала до Приднепровья.
В целом керамические изделия неолитического поселения Кальмиус не укладываются в какой-то единый культурный стандарт. Определенная разница в способах орнаментации заметна даже при сравнении материалов двух соседних раскопов. Это порождает своеобразную проблемную ситуацию. Исследователями неоднократно отмечалось, что бассейн р. Кальмиус был местом, где смыкались территории нижне-донской, азоводнепровской и сурской культур [9, с. 22].

Своеобразным хронологическим индикатором комплекса является фрагмент венчика, близкий к воротничковым венчикам позднего неолита - раннего энеолита (см. рис. $5,4)$. Венчики с подобным орнаментом характерны для керамики Лысогорского могильника в Поднепровье, который Д.Я. Телегин включает в круг могильников Мариупольского типа [15, с. 73-76], а Н.С. Котова относит к неолитической азово-днепровской культуре [9, c. 87]. Такая же керамика встречена и в Никольском могильнике [14, с. 7-83].

\section{Выводы}

1. Культурный слой неолитического поселения в историческом центре г. Мариуполя претерпел существенные постдепозиционные изменения и сохранился до наших дней в виде залегающего в ископаемой голоценовой почве горизонта культурных остатков. В почвенном горизонте они растянуты по вертикали, а также подверглись плоскостному смыву. Комплексность и обилие культурных остатков позволяют предполагать существование здесь стационарного поселка.

2. Преобладание в коллекции кремневых изделий мелких изношенных орудий и чешуек, доминирование среди керамических фрагментов мелких обломков, выраженные следы починки глиняной посуды, обилие мелких осколков среди фаунистических остатков свидетельствуют об интенсивной переработке населением поселка пищевых и минеральных ресурсов.

3. Комплексы кремневых орудий и изделий из мягких пород камня из неолитического слоя поселения Кальмиус и Мариупольского могильника показывают близкую степень сходства, что позволяет относить их к одно- 
му культурному типу. Следует признать, что один из эталонных признаков Мариупольского культурного типа - наличие крупных отжимных пластин - нуждается в коррекции с учетом настоящей публикации.

4. Неолитические материалы стоянки Кальмиус следует рассматривать в качестве синкретического культурного комплекса, бытовавшего относительно непродолжительное время в пределах конца неолитической эпохи. Несмотря на имеющиеся отличия, в целом керамический комплекс синхронен периоду I-A азово-днепровской культуры или I периоду нижне-донской культуры. Рассмотренные в статье памятники находились на границе больших культурных ареалов. В керамике поселения Кальмиус доминирует азово-днепровский компонент, что отражает широкие культурные связи жителей поселка с азово-днепровским населением. В небольшом количестве встречена также керамика, характерная для нижне-донской культуры. Этот комплекс является самым восточным известным памятником с выраженным набором керамики азово-днепровской культуры. Мариупольский могильник включается многими исследователями в круг памятников нижне-донской неолитической культуры.

Сочетание признаков соседних культурных типов отражает сложность этнокультурного развития в низовьях р. Кальмиус в неолитическую эпоху, возможно, в рамках модели культурной непрерывности. Мозаичность культурных признаков Мариупольской культурно-исторической общности еще раз подтверждает факт сложения общности на местной основе.

\section{СПИСОК ЛИТЕРАТУРЫ}

1. Васильев, И. Б. Могильник у с. Съезжее на р. Самаре / И. Б. Васильев, Г. И. Матвеева // Советская археология. - 1979. - № 4. - С. 147-167.

2. Васильев, И. Б. Энеолит восточно-европейской лесостепи / И. Б. Васильев, А. Т. Синюк. - Куйбышев, 1985.-117 c.

3. Горбов, В. Н. На границе культур: неолитический слой поселения Кальмиус и Мариупольский могильник / В. Н. Горбов, Р. П. Божко // Північне Приазов'я в епоху кам'яного віку - єнеоліту. - Мелітополь, смт. Мирне, 2013. - С. 34-40.

4. Даниленко, В. Н. Неолит Украины / В. Н. Даниленко. - Киев : Наукова думка, 1969. - 257 с.
5. Коваль, Ю. Г. Кремневый комплекс неолитического слоя поселения Кальмиус в современной черте г. Мариуполя (предварительное сообщение) / Ю. Г. Коваль, С. М. Дегерменджи // Північне Приазов'я в епоху кам'яного віку - єнеоліту. - Мелітополь, смт. Мирне, 2013. - С. 79-87.

6. Колесник, А. В. Кремневый комплекс Мариупольского могильника / А. В. Колесник // Самарский научный вестник. - 2016. - № 2 (15). - С. 67-74.

7. Колесник, А. В. Неолитический слой поселения Кальмиус в Мариуполе. Каменные изделия / А. В. Колесник, В. Н. Горбов // Вестник Волгоградского государственного университета. Серия 4, История. Регионоведение. Международные отношения. - 2016. - Т. 21, № 2. - C. 9-24. - DOI: http://dx.doi. org/10.15688/jvolsu4.2016.2.1.

8. Котова, Н. С. К проблеме контактов азоводнепровской и днепро-донецкой культур / Н. С. Котова // Каменный век на территории Украины: некоторые аспекты хозяйства и этнокультурных связей. - Киев : Наукова думка. 1990. - С. 39-47.

9. Котова, Н. С. Неолитизация Украины / Н. С. Котова. - Луганск : Шлях, 2002. - 268 с.

10. Котова, Н. С. Поздняя Сурская культура и ее окружение / Н. С. Котова, О. В. Тубольцев // Древности Степного Причерноморья и Крыма. - Запорожье, 1992. - Вып. III. - С. 8-23.

11. Котова, Н. С. Поховальний обряд Маріупольского могильника / Н. С. Котова // Археологія. -1990 . - № 3. - С. $48-56$.

12. Макаренко, М. Маріюпільський могильник / М. Макаренко. - Київ : Вид-во ВУАК, 1933. - 151 с.

13. Столяр, А. Д. Мариупольский могильник как исторический источник (опыт историко-культурного анализа памятника) / А. Д. Столяр // Советская археология. -1955. - Т. 23. - С. 17-37.

14. Телегін, Д. Я. Дніпро-донецька культура / Д. Я. Телегін. - Київ, 1969. - 254 с.

15. Телегин, Д. Я. Неолитические могильники мариупольского типа / Д. Я. Телегин. - Киев : Наукова думка, 1991. -96 с.

16. Товкайло, Н. Т. О восточных связях буго-днестровской культуры (по материалам поселения Пугач) / Н. Т. Товкайло // Каменный век на территории Украины. - Київ : Наукова думка, 1990. - С. 48-54.

\section{REFERENCES}

1. Vasilyev I.B., Matveeva G.I. Mogilnik u s. Syezzhee na r. Samare [The Burial Ground in the Syezzhee Village on the Samara River]. Sovetskaya arkheologiya, 1979, no. 4, pp. 147-167.

2. Vasilyev I.B., Sinyuk A.T. Eneolit vostochnoevropeyskoy lesostepi [Eneolithic of the Eastern European Forest-Steppe Zone]. Kuibyshev, 1985. 117 p. 
3. Gorbov N.V., Bozhko R.P. Na granitse kultur: neoliticheskiy sloy poseleniya Kalmius i Mariupolskiy mogilnik [On the Border of Cultures: a Neolithic Layer of the Settlement of Kalmius and the Mariupol Burial Ground]. Pivnichne Priazovya v epokhu kamyanogo viku - eneolitu [Azov Sea Cost during Stone Age Paleometal Age]. Melitopol, smt. Mirne Publ., 2013, pp. 34-40.

4. Danilenko V.N. Neolit Ukrainy [Neolithic of Ukraine]. Kiev, Naukova dumka Publ., 1969. 257 p.

5. Koval Yu.G., Degermendzhi S.M. Kremnevyy kompleks neoliticheskogo sloya poseleniya Kalmius v sovremennoy cherte g. Mariupolya (predvaritelnoe soobshchenie) [A Flint Complex of a Neolithic Layer of the Settlement of Kalmius in Modern Borders of Mariupol (the Preliminary Report)]. Pivnichne Priazovya $v$ epokhu kamyanogo viku - eneolitu [Azov Sea Cost during Stone Age - Paleometal Age]. Melitopol, smt. Mirne Publ., 2013, pp. 79-87.

6. Kolesnik A.V. Kremnevyy kompleks Mariupolskogo mogilnika [Flint Complex of the Mariupol Burial]. Samarskiy nauchnyy vestnik, 2016, no. 2 (15), pp. 67-74.

7. Kolesnik A.V., Gorbov V.N. Neoliticheskiy sloy poseleniya Kalmius v Mariupole. Kamennye izdeliya [Neolithic Layer of Settlement of Kalmius in Mariupol. Stone Products]. Vestnik Volgogradskogo gosudarstvennogo universiteta. Seriya 4. Istoriya. Regionovedenie. Mezhdunarodnye otnosheniya [Science Journal of Volgograd State University. History. Area Studies. International Relations], 2016, vol. 21, no. 2, pp. 9-24.

8. Kotova N.S. K probleme kontaktov azovodneprovskoyi dnepro-donetskoy kultur [On the Problem of Azov-Dnepr and Dnepr-Donets Cultural Contacts]. Kamennyy vek na territorii Ukrainy: nekotorye aspekty khozyaystva i etnokulturnykh svyazey [Stone Age on the Territory of Ukraine: Some Aspects of the Economy and the Ethnic and Cultural Connections]. Kiev, Naukova Dumka Publ., 1990, pp. 39-47.

9. Kotova N.S. Neolitizatsiya Ukrainy [Neolithic Progress in Ukraine]. Lugansk, Shkyakh Publ., 2002. 268 p.

10. Kotova N.S., Tuboltsev O.V. Pozdnyaya Surskaya kultura i ee okruzhenie [Late Sura Culture and Its Environment]. Drevnosti Stepnogo Prichernomorya i Kryma. Vyp. 3 [Antiquities of Steppe Black Sea Region and the Crimea. Iss. 3]. Zaporozhye, 1992, pp. 8-23.

11. Kotova N.S. Pokhovalniy obryad Mariupolskogo mogilnika [Funeral Rite of the Mariupol Burial Ground]. Arkheologiya, 1990, no. 3, pp. 48-56.

12. Makarenko M.E. Mariupolskiy mogilnik [Mariupol Burial Ground]. Kiev, VUAK Publ., 1933.151 p.

13. Stolyar A.D. Mariupolskiy mogilnik kak istoricheskiy istochnik (opyt istoriko-kulturnogo analiza pamyatnika) [Mariupol Burial Ground as a Historical Source (the Experience of Historical and Cultural Analysis of the Monument)]. Sovetskaya arkheologiya, 1955, vol. XVIII, pp. 17-37.

14. Telegin D.Ya. Dnipro-donetska kultura [Dnepr-Donetsk Culture]. Kiev, 1969. 254 p.

15. Telegin D.Ya. Neoliticheskie mogilniki mariupolskogo tipa [Neolithic Burial of the Mariupol Type]. Kiev, Naukova dumka Publ., 1991. 96 p.

16. Tovkaylo N.T. O vostochnykh svyazyakh bugo-dnestrovskoy kultury (po materialam poseleniya Pugach) [About Eastern Communications of BugDnester Culture (Based on Settlement of Pugach)]. Kamennyy vek na territorii Ukrainy [Stone Age on the Territory of Ukraine]. Kiev, Naukova dumka Publ., 1990, pp. 48-54.

\section{Information About the Authors}

Vladimir N. Gorbov, Researcher, Donetsk Republican (Regional) Museum, Chelyuskintsev St., 189-a, 83048 Donetsk, Ukraine, gorbov.vn@gmail.com.

Aleksandr V. Kolesnik, Candidate of Sciences (History), Associate Professor, Department of Historiography, Source Study, Archaeology and Methods of Teaching History, Donetsk State University, Universitetskaya St., 20, 83005 Donetsk, Ukraine, akolesnik2007@mail.ru.

\section{Информация об авторах}

Владимир Николаевич Горбов, научный сотрудник, Донецкий республиканский краеведческий музей, ул. Челюскинцев, 189-a, 83048 г. Донецк, Украина, gorbov.vn@,gmail.com.

Александр Викторович Колесник, кандидат исторических наук, доцент, кафедра историографии, источниковедения, археологии и методики преподавания истории, Донецкий национальный университет, ул. Университетская, 20, 83005 г. Донецк, Украина, akolesnik2007@mail.ru. 